\title{
Establishing Consensus in Knowledge Base Creation of Medicinal Plants of African Traditional Medicine
}

\author{
Awoniran O.M. \\ Dept. of Comp. Sc. \& Info. \\ Technology, \\ Bowen University, Iwo, Nigeria
}

\author{
Soriyan H.A. \\ Department of Computer Science \\ and Engineering, Obafemi Awolowo \\ University, lle-Ife, Nigeria
}

\author{
Elujoba A.A. \\ Department of Pharmacognosy, \\ Obafemi Awolowo University, Ile-Ife, \\ Nigeria
}

\begin{abstract}
This research work creates a holistic knowledge base of medicinal plants in African traditional medicine practice. The methodology employed in the research work involves three stages of the Delphi technique conducted for nine (9) experts in the ATM practice. Knowledge collation and elimination were carried out after each stage of the knowledge elicitation process and the level of agreement in the elicited knowledge was measured using the Fleiss' kappa agreement analysis (k). Results from the work show a progression in the agreements on the medicinal plants and herbs that are useful for the treatment and/or management of some ailments. At the final stage of the interview, a perfect agreement was achieved. In conclusion, the use of the Delphi technique as a knowledge elicitation tool aided a perfect agreement in the creation of a knowledge base of medicinal plants of African traditional medicine practice.
\end{abstract}

\section{General Terms}

Reasoning, Knowledge Extraction, and Knowledge Management.

\section{Keywords}

Knowledge-Based Systems, Knowledge Elicitation, Delphi Knowledge Elicitation Technique, African Traditional Medicine Practice.

\section{INTRODUCTION}

A knowledge base is a set of underlying facts, assumptions, and rules in a knowledge domain [1]. These facts, assumptions, or rules range from simple assertions to complex procedures about entities that may really or fundamentally exist in a knowledge domain. The creation of a knowledge base usually requires a process of knowledge elicitation from experts in the domain [2]. During the process, domain experts provide knowledge about various aspects of the knowledge domain. Various methods are in existence for the purpose of knowledge elicitation. These include interviews, observation, storytelling, round-table among others [3]. The results of an elicitation process are usually qualitative in nature [4]. In situations whereby there is more than one expert from which knowledge was elicited, establishing a consensus from the qualitative data obtained then becomes a task; otherwise, the development of a holistic knowledge base would be near impossible or at best, subjective. This problem is more complex in knowledge domains with unstructured data [5]. Unstructured data is a type of data that cannot be easily represented using tables [6]. This is because they lack a definite model and are not organized in a pre-defined manner [7]. Data and information in most knowledge domains are unstructured in nature [8]. This makes the process of knowledge elicitation and ultimately the creation of knowledge bases in these domains quite difficult. Such is the case of the medicinal plants of the African traditional medicine (ATM) practice.

In the ATM practice, medicinal plants processing, drug preparation, and therapy knowledge are unstructured in nature [9]. A major component of the therapeutic aspect of the ATM practice is the handling, pre-processing, usage, and in-depth knowledge of medicinal plants. This includes knowledge of the specific medicinal plants that could be used for the treatment of various illnesses and ailments, the medicinal parts of such plants, and the specific preparation methods of the plants. The knowledge of this form and determine the expertise of the practitioners of the ATM. The most basic aspect of the practice is the knowledge of the exact medicinal plants that could be used in very specific circumstances. Therefore, the establishment of a consensus on the specific medicinal plants that are useful for specific ailments is crucial in the creation of a knowledge base of medicinal plants of ATM practice.

Delphi technique provides a means of achieving consensus among a group of expert knowledge donors [10]. The technique aims at acquiring the most reliable consensus of opinion from a group of experts through a series of intensive interviews along with an opinion control feedback [11].

This research work aims at achieving a consensus of medicinal plants that are useful in the treatment or management of some ailments. This was done in order to create a knowledge base of medicinal plants and herbs in the ATM practice.

\section{RELATED WORKS}

Knowledge can be defined as the practical or theoretical understanding of facts, descriptions, or principles of a particular subject [12]. These facts, descriptions, or principles are usually gathered by education or experience. Knowledge can be implicit or explicit in nature. Implicit knowledge is also regarded as tacit knowledge and it is the type of knowledge that basically resides in the mind of the knowledge owner [13]. This type of knowledge is hard to articulate and the knowledge owners, usually, cannot describe it other than their own skillful display. Explicit knowledge, on the other hand, is the knowledge that has been codified and documented using some sort of media [13].

Most expert-driven knowledge is implicit in nature and hence difficult to codify. Also, expert-driven knowledge is a function of the perceptions and experiences of the individual experts who possess the knowledge [14]. These facts are reasons why knowledge is regarded as a complex entity. This complex nature of knowledge inferentially makes its elicitation more than the simple process of data acquisition. 
Methods available for knowledge elicitation include interviews, storytelling, laddering, protocol analysis, critical decision method, concepts sorting, etc. [15].

Furthermore, the complex nature of knowledge results makes the result of its elicitation to be most probably represented as a subjective distribution [16]. These distributions play an important role in inference and decision-making in the development of knowledge models [17]. Methods by which knowledge elicitation can be made scientific in order to forestall subjectivity were proposed using protocols [18]. The work argues that by following a recognized protocol that is designed to address and minimize cognitive biases that experts are prone to when making judgments, subjectivity in such judgments will likely be eliminated.

Again, the consensus of elicited knowledge could also be achieved using information integration [19]. Cognitive task analysis for information triangulation was proposed as a method for information integration of the needs, goals, and design requirements for the design of a newborn intensive care unit [20]. The method involves a representative definition of design goals by accounting for the perspectives of all user groups involved with the unit. Results from the work show that each role has a unique perspective and a specific detail based on the role goals. The work concludes that source triangulation should be employed as part of methods to achieve design objectives in complex socio-technical systems. Also, the Delphi technique was used for establishing consensus on core competencies of the model of community and family medicine department in India [21]. In the study, experts were contacted by e-mail and their feedbacks were analysed. Results from the work show consensus being reached on various core competencies in the department which are "Clinician", "Primary-Care Physician", and "Professionalism". However, the work claimed that more experienced experts were less consistent in their responses. Furthermore, a modified Delphi technique was employed to inform the development of best practices in interprofessional training for collaborative primary healthcare [22]. In the study, a modified Delphi technique was used in knowledge elicitation using three rounds of interviews. The first round of interviews was carried out with the use of questionnaires. The qualitative results obtained was then written out in a Likert scale-like version and presented to the respondents in the second round of interview. Finally, the results were collated and re-presented to the respondents in the final round of interviews. The work demonstrated a successful elicitation of knowledge from a heterogeneous panel of stakeholders in primary health education and training [23].

Specifically, in ATM practice, a framework for knowledge capture was proposed to enhance the codification and preservation of knowledge in ATM treatment of Malaria [24]. The methodology adopted in the work involves the elicitation of knowledge by means of interviews from ATM practitioners. The knowledge derived was structured and then built into a knowledge-based system (KBS). The KBS was tested along with experts in the field and a high level of agreement was recorded between the KBS and the experts. Finally, research on factors influencing indigenous knowledge data elicitation from herbal medicinal practitioners was conducted in south-western Nigeria [25]. The work highlights the fact that the lack of or inadequate documentation of indigenous knowledge contributes majorly to the extinction (or the threat of it) of such knowledge. Methods from the work include interviews and direct observation of processes in traditional medicine. Results from the work show that familiarity and compensation are key factors that facilitate openness of knowledge holders to share information.

\section{METHODOLOGY}

The methodology employed in the research work involves firstly, the selection and recruitment of ATM practitioners into the study. Thereafter, the initial interview with a designed questionnaire, knowledge collation, concordance and agreements analysis, and finally, follow-up interviews were conducted. A diagram showing the methodological framework is shown in Figure 1.

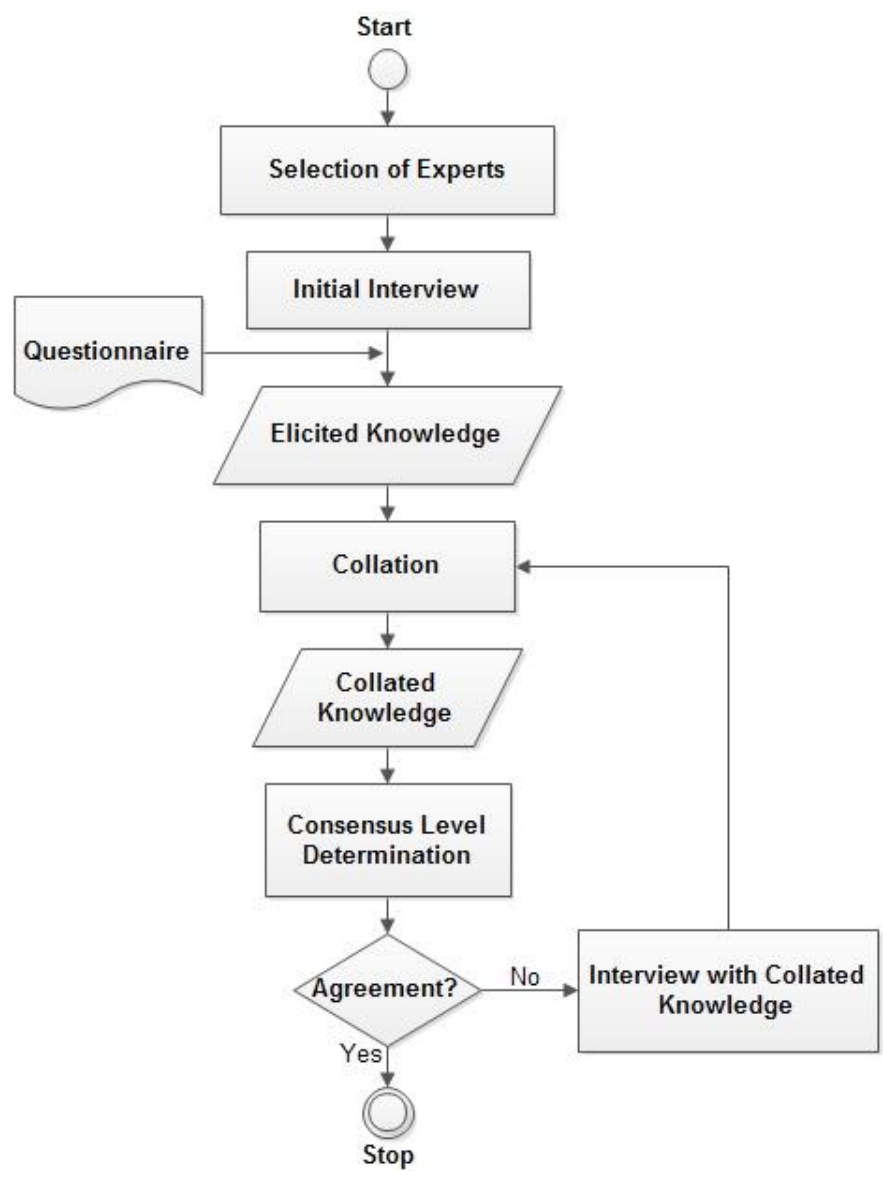

Figure 1. The Methodological Framework

\subsection{Selection of Experts}

Four criteria were considered in the selection of the panel of experts that took part in the Delphi knowledge elicitation process. Firstly, experts whose coverage area is in southwestern Nigeria were considered. This was done in order to obtain precise responses from the panel members. Also, the medicinal plants available varies across the regions of the country, therefore achieving consensus across multiple regions might be impossible. [26, 27].

Secondly, experts that were trained by the master-servant method of apprenticeship were recruited into the study. This is to ensure that the experts have undergone the proper requisite training of being a practitioner in the domain. Again, the master-servant method of apprenticeship provides trainees with hands-on experience.

Thirdly, experts who practice the trade on full-time basis and specializes in ailments that have been accepted to be effectively treated or managed with African medicinal plants were considered.

Finally, experts who consult with patients on a regular basis and effectively treats or manages the ailments presented by the patients were considered. 
The ailments considered in this study are Asthma, Chicken Pox, Cold \& Catarrhal, Convulsions, Cough, Diabetes, Diarrhea, Eczema, Hypertension, Erectile Dysfunction, Malaria, Pile, Rheumatism, Ring Worm, Stomach Disorder, Typhoid, and Ulcer. They are labeled as D1 to D17 respectively.

\subsection{The Initial Interview}

The initial interview was conducted with the use of an interview guide. Major aspects considered in the interview guide are "expertise in traditional medicine practice", "knowledge acquisition in traditional medicine practice", "knowledge impact in traditional medicine practice", "the practice of African traditional medicine (diseases and treatments)", and "the practice of African traditional medicine (pharmaceutical aspects)". The interview questions were designed to enable discussions on the various aspects of the interview. The language of communication of the interviews was the Yoruba language. After the interviews, language transcription was carried out to transcribe the results obtained to the English language.

\subsection{Knowledge Collation}

Upon the successful completion of the initial interviews, medicinal plants and herbs that have the highest selections were collated. Thereafter, agreement analysis was then conducted on the elicited knowledge.

\subsection{Consensus Analysis}

The level of agreement in the elicited knowledge was determined by analyzing the level of agreement in the elicited knowledge. This was estimated using the Fleiss' kappa agreement analysis (k). The Fleiss' kappa agreement (k) has values that range from 0.0 to $1.0[28,29]$. Value 0.0 denotes minimum agreement while value 1.0 denotes maximum agreement. However, value 8.0 is considered as an almost perfect agreement.

The equation for Fleiss' kappa agreement analysis $(k)$ is given in equation 1 below where $\overline{\boldsymbol{p}}$ denotes the extent to which respondents agree for the treatment/management of a particular disease/ailment and $\overline{\boldsymbol{p}_{\boldsymbol{e}}}$ denotes the agreements for herbs used in treating a particular disease/ailment.

$$
\boldsymbol{k}=\frac{\overline{\boldsymbol{p}}-\overline{\boldsymbol{p}_{e}}}{1-\overline{\boldsymbol{p}_{e}}}
$$

eqn 1

To compute this, let $n$ be the total number of experts (9), $k$ is the highest number of medicinal plants/herbs obtained for a particular ailment at a particular round of interview, the categories are indexed as $j=1$ to $k$ for a particular ailment and $n_{k}$ represent the number of experts who gave $j$ number of medicinal plants/herbs for a particular ailment. The proportions of assignments to a category $j\left(p_{j}\right)$ is estimated as shown in equation 2 ;

$$
\boldsymbol{p}_{j}=\frac{\boldsymbol{n}_{j}}{\boldsymbol{n}}
$$

The agreements for herbs used in treating a particular disease/ailment $\left(\overline{\boldsymbol{p}_{\boldsymbol{e}}}\right)$ is then estimated as shown in equation 3;

$\overline{\boldsymbol{p}_{e}}=\sum_{j=1}^{k} \boldsymbol{p}_{j}^{2}$

The extent to which the experts agree for the treatment/management of a particular disease/ailment $(\overline{\boldsymbol{p}})$ is then estimated as shown in equation 4 ;

$$
\overline{\boldsymbol{p}}=\frac{1}{n(n-1)}\left[\left(\sum_{j=1}^{k} \boldsymbol{n}_{j}^{2}\right)-(n)\right] \text { eqn } 4
$$

$\overline{\boldsymbol{p}}$ and $\overline{\boldsymbol{p}_{\boldsymbol{e}}}$ is then be substituted into equation 1 above to obtain $\boldsymbol{k}$.

\subsection{Follow-Up Interviews}

After the agreement level determination, the practitioners were again asked to select the medicinal plants and herbs for the treatment/management of the various diseases from the collated result of the previous interview. Knowledge collation and agreement level determination were then carried out once again. This process was repeated until a perfect agreement was obtained.

\section{RESULTS AND DISCUSSION}

A total of nine (9) experts were recruited into the study using the criteria for the selection of experts outlined in section 3.0. After the initial interview, ten medicinal plants and herbs were obtained for D1, seven for D2, nine for D3, thirteen for D4, nine for D5, eight for D6, ten for D7, three for D8, seven for D9, nine for D10, fifteen for D11, Six for D12, nine for D13, three for D14, nine for D15, thirteen for D16, and seven for D17. This is presented in Table 1.

In the second round of interviews, the practitioners were asked to select the medicinal plants and herbs useful in the treatment/management of the various diseases from the list of medicinal plants and herbs obtained at the first round of interviews. Table 2 shows the result of the second round of interviews. Afterward, the collation of the medicinal plants and herbs was carried out.

Again, in the third round of interviews, the practitioners were asked to select medicinal plants and herbs useful in the treatment/management of the various diseases from the list of medicinal plants and herbs obtained at the second round of interviews. Table 3 shows the result of the third round of interviews. In the third round of interviews, all respondents agree that all the medicinal plants and herbs presented for the treatment/management of various ailments were useful in the treatment of the ailments. The medicinal plants obtained at each round of the process are shown in Table 4.

Table 1. Number of Herbs obtained from Respondents after the Initial Interview

\begin{tabular}{|c|c|c|c|c|c|c|c|c|c|c|c|c|c|c|c|c|c|}
\hline & $\mathbf{D}_{\mathbf{1}}$ & $\mathbf{D}_{\mathbf{2}}$ & $\mathbf{D}_{\mathbf{3}}$ & $\mathbf{D}_{\mathbf{4}}$ & $\mathbf{D}_{\mathbf{5}}$ & $\mathbf{D}_{\mathbf{6}}$ & $\mathbf{D}_{\mathbf{7}}$ & $\mathbf{D}_{\mathbf{8}}$ & $\mathbf{D}_{\mathbf{9}}$ & $\mathbf{D}_{\mathbf{1 0}}$ & $\mathbf{D}_{\mathbf{1 1}}$ & $\mathbf{D}_{\mathbf{1 2}}$ & $\mathbf{D}_{\mathbf{1 3}}$ & $\mathbf{D}_{\mathbf{1 4}}$ & $\mathbf{D}_{\mathbf{1 5}}$ & $\mathbf{D}_{\mathbf{1 6}}$ & $\mathbf{D}_{\mathbf{1 7}}$ \\
\hline Collated & 10 & 7 & 9 & 13 & 9 & 8 & 10 & 3 & 7 & 9 & 15 & 6 & 9 & 3 & 9 & 13 & 7 \\
\hline
\end{tabular}


Table 2. Number of Herbs Selected by Respondents after the Second Round of Interview

\begin{tabular}{|r|r|r|r|r|r|r|r|r|r|r|r|r|r|r|r|r|r|}
\hline \multicolumn{1}{|c|}{ Resp } & $\mathbf{D}_{\mathbf{1}}$ & $\mathbf{D}_{\mathbf{2}}$ & $\mathbf{D}_{\mathbf{3}}$ & $\mathbf{D}_{\mathbf{4}}$ & $\mathbf{D}_{\mathbf{5}}$ & $\mathbf{D}_{\mathbf{6}}$ & $\mathbf{D}_{\mathbf{7}}$ & $\mathbf{D}_{\mathbf{8}}$ & $\mathbf{D}_{\mathbf{9}}$ & $\mathbf{D}_{\mathbf{1 0}}$ & $\mathbf{D}_{\mathbf{1 1}}$ & $\mathbf{D}_{\mathbf{1 2}}$ & $\mathbf{D}_{\mathbf{1 3}}$ & $\mathbf{D}_{\mathbf{1 4}}$ & $\mathbf{D}_{\mathbf{1 5}}$ & $\mathbf{D}_{\mathbf{1 6}}$ & $\mathbf{D}_{\mathbf{1 7}}$ \\
\hline $\mathbf{1}$ & 7 & 5 & 7 & 10 & 6 & 7 & 9 & 2 & 6 & 7 & 14 & 5 & 7 & 2 & 7 & 11 & 5 \\
\hline $\mathbf{2}$ & 8 & 4 & 6 & 11 & 6 & 6 & 9 & 2 & 5 & 8 & 13 & 4 & 7 & 2 & 7 & 12 & 6 \\
\hline $\mathbf{3}$ & 7 & 4 & 7 & 11 & 5 & 6 & 8 & 2 & 6 & 7 & 13 & 3 & 8 & 2 & 7 & 11 & 5 \\
\hline $\mathbf{4}$ & 6 & 3 & 7 & 11 & 6 & 6 & 9 & 2 & 5 & 7 & 10 & 4 & 7 & 2 & 7 & 12 & 5 \\
\hline $\mathbf{5}$ & 7 & 4 & 7 & 10 & 4 & 6 & 9 & 2 & 5 & 7 & 13 & 4 & 6 & 2 & 6 & 11 & 5 \\
\hline $\mathbf{6}$ & 7 & 4 & 6 & 11 & 5 & 7 & 9 & 2 & 5 & 7 & 11 & 4 & 7 & 2 & 7 & 10 & 6 \\
\hline $\mathbf{7}$ & 6 & 3 & 7 & 11 & 5 & 6 & 9 & 2 & 5 & 7 & 13 & 4 & 5 & 2 & 7 & 11 & 5 \\
\hline $\mathbf{8}$ & 7 & 4 & 6 & 10 & 6 & 6 & 8 & 2 & 5 & 6 & 10 & 3 & 7 & 2 & 6 & 11 & 5 \\
\hline $\mathbf{9}$ & 7 & 3 & 7 & 11 & 6 & 5 & 9 & 2 & 5 & 5 & 11 & 2 & 7 & 2 & 5 & 10 & 4 \\
\hline Collated & 8 & 5 & 8 & 12 & 7 & 7 & 9 & 2 & 5 & 8 & 14 & 5 & 8 & 2 & 8 & 12 & 6 \\
\hline
\end{tabular}

Table 3. Number of Herbs Selected by Respondents after the Third Round of Interview

\begin{tabular}{|r|r|r|r|r|r|r|r|r|r|r|r|r|r|r|r|r|r|}
\hline \multicolumn{1}{|c|}{ Resp } & $\mathbf{D}_{\mathbf{1}}$ & $\mathbf{D}_{\mathbf{2}}$ & $\mathbf{D}_{\mathbf{3}}$ & $\mathbf{D}_{\mathbf{4}}$ & $\mathbf{D}_{\mathbf{5}}$ & $\mathbf{D}_{\mathbf{6}}$ & $\mathbf{D}_{\mathbf{7}}$ & $\mathbf{D}_{\mathbf{8}}$ & $\mathbf{D}_{\mathbf{9}}$ & $\mathbf{D}_{\mathbf{1 0}}$ & $\mathbf{D}_{\mathbf{1 1}}$ & $\mathbf{D}_{\mathbf{1 2}}$ & $\mathbf{D}_{\mathbf{1 3}}$ & $\mathbf{D}_{\mathbf{1 4}}$ & $\mathbf{D}_{\mathbf{1 5}}$ & $\mathbf{D}_{\mathbf{1 6}}$ & $\mathbf{D}_{\mathbf{1 7}}$ \\
\hline $\mathbf{1}$ & 7 & 4 & 7 & 11 & 5 & 6 & 7 & 2 & 5 & 7 & 13 & 4 & 7 & 2 & 7 & 11 & 5 \\
\hline $\mathbf{2}$ & 7 & 4 & 7 & 11 & 5 & 6 & 7 & 2 & 5 & 7 & 13 & 4 & 7 & 2 & 7 & 11 & 5 \\
\hline $\mathbf{3}$ & 7 & 4 & 7 & 11 & 5 & 6 & 7 & 2 & 5 & 7 & 13 & 4 & 7 & 2 & 7 & 11 & 5 \\
\hline $\mathbf{4}$ & 7 & 4 & 7 & 11 & 5 & 6 & 7 & 2 & 5 & 7 & 13 & 4 & 7 & 2 & 7 & 11 & 5 \\
\hline $\mathbf{5}$ & 7 & 4 & 7 & 11 & 5 & 6 & 7 & 2 & 5 & 7 & 13 & 4 & 7 & 2 & 7 & 11 & 5 \\
\hline $\mathbf{6}$ & 7 & 4 & 7 & 11 & 5 & 6 & 7 & 2 & 5 & 7 & 13 & 4 & 7 & 2 & 7 & 11 & 5 \\
\hline $\mathbf{7}$ & 7 & 4 & 7 & 11 & 5 & 6 & 7 & 2 & 5 & 7 & 13 & 4 & 7 & 2 & 7 & 11 & 5 \\
\hline $\mathbf{8}$ & 7 & 4 & 7 & 11 & 5 & 6 & 7 & 2 & 5 & 7 & 13 & 4 & 7 & 2 & 7 & 11 & 5 \\
\hline $\mathbf{9}$ & 7 & 4 & 7 & 11 & 5 & 6 & 7 & 2 & 5 & 7 & 13 & 4 & 7 & 2 & 7 & 11 & 5 \\
\hline Collated & 7 & 4 & 7 & 11 & 5 & 6 & 7 & 2 & 5 & 7 & 13 & 4 & 7 & 2 & 7 & 11 & 5 \\
\hline
\end{tabular}

Table 4. Results at each Round of the Delphi Process

\begin{tabular}{|c|c|c|c|c|}
\hline $\mathbf{S} / \mathbf{N}$ & $\begin{array}{l}\text { Disease/ } \\
\text { Ailment }\end{array}$ & $\begin{array}{l}\text { Medicinal Plants for Treatment } \\
\text { after the First Round of } \\
\text { Interview }\end{array}$ & $\begin{array}{l}\text { Medicinal Plants for Treatment } \\
\text { after the Second Round of } \\
\text { Interview }\end{array}$ & $\begin{array}{l}\text { Medicinal Plants for Treatment } \\
\text { after the Third Round of } \\
\text { Interview }\end{array}$ \\
\hline 1 & Asthma & $\begin{array}{l}\text { Baobab, Garlic, Giant Milk Weed, } \\
\text { Asthma plant, Indian shot, Silk } \\
\text { Cotton Tree, Clausena, } \\
\text { Desmodium, Starburr, Heliotrope. }\end{array}$ & $\begin{array}{l}\text { Baobab, Garlic, Giant Milk Weed, } \\
\text { Asthma plant, Indian shot, Silk } \\
\text { Cotton Tree, Clausena, } \\
\text { Desmodium. }\end{array}$ & $\begin{array}{l}\text { Baobab, Garlic, Giant Milk Weed, } \\
\text { Asthma plant, Indian shot, Silk } \\
\text { Cotton tree, Desmodium. }\end{array}$ \\
\hline 2 & Chicken Pox & $\begin{array}{l}\text { Alligator Pepper, Tallow Tree, } \\
\text { Sasswood, Sesame, Cayenne } \\
\text { Pepper, Tea bush, Tea bush. }\end{array}$ & $\begin{array}{l}\text { Alligator Pepper, Tallow Tree, } \\
\text { Sasswood, Sesame, Cayenne } \\
\text { Pepper. }\end{array}$ & $\begin{array}{l}\text { Alligator Pepper, Tallow Tree, } \\
\text { Sasswood, Sesame. }\end{array}$ \\
\hline 3 & $\begin{array}{ll}\text { Cold } & \& \\
\text { Catarrhal } & \end{array}$ & $\begin{array}{l}\text { Guava, Garlic, Lemon Juice, } \\
\text { Flacourtia, Moringa Tree, Sweet } \\
\text { and Hairy Basil, Cayenne Pepper, } \\
\text { Starburr, Ginger. }\end{array}$ & $\begin{array}{l}\text { Guava, Garlic, Lemon Juice, } \\
\text { Flacourtia, Moringa Tree, Sweet } \\
\text { and Hairy Basil, Cayenne Pepper, } \\
\text { Starburr. }\end{array}$ & $\begin{array}{l}\text { Guava, Garlic, Lemon Juice, } \\
\text { Flacourtia, Moringa Tree, Sweet } \\
\text { and Hairy Basil, Cayenne Pepper. }\end{array}$ \\
\hline 4 & Convulsions & $\begin{array}{l}\text { Cascarilla, Desmodium, Cotton, } \\
\text { Heliotrope, Flacourtia, Moringa } \\
\text { Tree, Pergularia, Guava, Sweet } \\
\text { basil, Secamore, Hog plum, Latex, } \\
\text { Adenia. }\end{array}$ & $\begin{array}{l}\text { Cascarilla, Desmodium, Cutton, } \\
\text { Heliotrope, Flacourtia, Moringa } \\
\text { Tree, Pergularia, Guava, Sweet } \\
\text { basil, Secamore, Hog plum, Latex. }\end{array}$ & $\begin{array}{l}\text { Cascarilla, Desmodium, Cutton, } \\
\text { Heliotrope, Flacourtia, Moringa } \\
\text { Tree, Pergularia, Guava, Sweet } \\
\text { basil, Secamore, Hog plum. }\end{array}$ \\
\hline 5 & Cough & $\begin{array}{l}\text { Crab's eye, Star burr, Bear's } \\
\text { breech, Adenia, Ginger, Lemon } \\
\text { Juice, Alligator Pepper, Tea bush, } \\
\text { Bitter leaf. }\end{array}$ & $\begin{array}{l}\text { Crab's eye, Starburr, Bear's } \\
\text { breech, Adenia, Ginger, Lemon } \\
\text { Juice, Alligator Pepper. }\end{array}$ & $\begin{array}{l}\text { Crab's eye, Starburr, Bear's } \\
\text { breech, Adenia, Ginger Lemon } \\
\text { Juice. }\end{array}$ \\
\hline 6 & Diabetes & $\begin{array}{l}\text { Stool wood, Seeds of Hunteria, } \\
\text { Bitter leaves, Moringa, Scent } \\
\text { Leaf, Dutchman's Pipe, Bitter leaf, } \\
\text { Wonderful kola. }\end{array}$ & $\begin{array}{l}\text { Stool wood, Seeds of Hunteria, } \\
\text { Bitter leaves, Moringa, Scent } \\
\text { Leaf, Dutchman's Pipe, Bitter } \\
\text { Leaf. }\end{array}$ & $\begin{array}{l}\text { Stool wood, Seeds of Hunteria, } \\
\text { Bitter leaves, Moringa, Scent } \\
\text { Leaf, Dutchman's Pipe. }\end{array}$ \\
\hline 7 & Diarrheal & $\begin{array}{l}\text { Latex, Connessi, Tea bush, Guava, } \\
\text { African rose Wood, Serpent wood, }\end{array}$ & $\begin{array}{l}\text { Latex, Connessi, Tea bush, Guava, } \\
\text { African rose Wood, Serpent wood, }\end{array}$ & 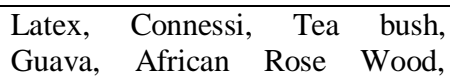 \\
\hline
\end{tabular}


Table 4. Results at each Round of the Delphi Process

\begin{tabular}{|c|c|c|c|c|}
\hline $\mathbf{S} / \mathbf{N}$ & $\begin{array}{l}\text { Disease/ } \\
\text { Ailment }\end{array}$ & $\begin{array}{l}\text { Medicinal Plants for Treatment } \\
\text { after the First Round of } \\
\text { Interview }\end{array}$ & $\begin{array}{l}\text { Medicinal Plants for Treatment } \\
\text { after the Second Round of } \\
\text { Interview }\end{array}$ & $\begin{array}{l}\text { Medicinal Plants for Treatment } \\
\text { after the Third Round of } \\
\text { Interview }\end{array}$ \\
\hline & & $\begin{array}{l}\text { Sterculia gum, Garlic, Bitter leaf, } \\
\text { Lemon juice. }\end{array}$ & Sterculia gum, Garlic, Bitter leaf. & Serpent wood, Garlic. \\
\hline 8 & Eczema & $\begin{array}{l}\text { Prickly Amaranth, Physic nut, } \\
\text { Mistletoe. }\end{array}$ & Prickly Amaranth, Physic nut. & Prickly Amaranth, Physic nut. \\
\hline 9 & Hypertension & $\begin{array}{l}\text { Moringa tree, Baobab, Adenia, } \\
\text { Cotton, Garlic, Ginger, Mistletoe. }\end{array}$ & $\begin{array}{l}\text { Moringa tree, Adenia, Cotton, } \\
\text { Garlic, Ginger, Mistletoe. }\end{array}$ & $\begin{array}{l}\text { Moringa tree, Adenia, Cotton, } \\
\text { Garlic, Ginger. }\end{array}$ \\
\hline 10 & $\begin{array}{l}\text { Erectile } \\
\text { Dysfunction }\end{array}$ & $\begin{array}{l}\text { Climbing black pepper, Cabbage } \\
\text { tree, Crimson thyme, Corynanthe } \\
\text { yohimbe, Bushveld, Bushveld, } \\
\text { Bowstring Hemp, Masquerade } \\
\text { stick, Wonderful kola. }\end{array}$ & $\begin{array}{l}\text { Climbing Black Pepper, Cabbage } \\
\text { Tree, Crimson Thyme, } \\
\text { Corynanthe Yohimbe, Bushveld, } \\
\text { Bushveld, Bowstring Hemp, } \\
\text { Wonderful Kola. }\end{array}$ & $\begin{array}{l}\text { Climbing Black Pepper, Cabbage } \\
\text { Tree, Crimson Thyme, } \\
\text { Corynanthe Yohimbe, Bushveld, } \\
\text { Bushveld, Bowstring Hemp. }\end{array}$ \\
\hline 11 & Malaria & $\begin{array}{l}\text { Baobab, Alligator pepper, Yellow } \\
\text { Allamanda, Tallow tree, Lemon } \\
\text { Grass, Cashew, Hunteria } \\
\text { umbellate, Mango, Stool wood, } \\
\text { Brimstone tree, Turmeric, } \\
\text { Dragon's Blood Tree, Serpent } \\
\text { Wood, Guava tree, African } \\
\text { Yellow Wood. }\end{array}$ & $\begin{array}{l}\text { Baobab, Alligator pepper, Yellow } \\
\text { Allamanda, Tallow tree, Lemon } \\
\text { Grass, Cashew, Hunteria } \\
\text { umbellate, Mango, Stool wood, } \\
\text { Brimstone tree, Dragon's Blood } \\
\text { Tree, Serpent Wood, Guava tree, } \\
\text { African Yellow Wood. }\end{array}$ & $\begin{array}{l}\text { Baobab, Yellow Allamanda, } \\
\text { Tallow tree, Lemon Grass, } \\
\text { Cashew, Hunteria umbellate, } \\
\text { Mango, Stool wood, Brimstone } \\
\text { tree, Dragon's Blood Tree, Serpent } \\
\text { Wood, Guava tree, African } \\
\text { Yellow Wood. }\end{array}$ \\
\hline 12 & Pile & $\begin{array}{l}\text { Crimson thyme, Balloon vine, } \\
\text { Bushveld, Asthma Plant, Lemon } \\
\text { juice, Bitter leaf. }\end{array}$ & $\begin{array}{l}\text { Crimson Thyme, Balloon Vine, } \\
\text { Bushveld, Asthma Plant, Bitter } \\
\text { Leaf. }\end{array}$ & $\begin{array}{l}\text { Crimson Thyme, Balloon Vine, } \\
\text { Bushveld, Asthma Plant. }\end{array}$ \\
\hline 13 & Rheumatism & $\begin{array}{l}\text { Crab's Eye, Acalypha, Starburr, } \\
\text { Alligator pepper, Balloon vine, } \\
\text { Christmas Bush, Frest crinum, } \\
\text { African Yellow Wood, Bushveld }\end{array}$ & $\begin{array}{l}\text { Crab's Eye, Acalypha, Starburr, } \\
\text { Alligator pepper, Balloon vine, } \\
\text { Christmas Bush, Frest crinum, } \\
\text { Bushveld }\end{array}$ & $\begin{array}{l}\text { Crab's Eye, Acalypha, Starburr, } \\
\text { Alligator pepper, Balloon vine, } \\
\text { Christmas Bush, Frest crinum. }\end{array}$ \\
\hline 14 & Ring Worm & $\begin{array}{l}\text { Prickly Amaranth, Physic nut, } \\
\text { Masquerade stick. }\end{array}$ & Prickly Amaranth, Physic nut. & Prickly Amaranth, Physic nut. \\
\hline 15 & $\begin{array}{l}\text { Stomach } \\
\text { Disorder }\end{array}$ & $\begin{array}{l}\text { Rough-Chaff herb, Mahogany, } \\
\text { Hemorrhage plant, Corpse } \\
\text { awakener, Bush candle tree, } \\
\text { Sandpaper tree, Starburr, Lemon } \\
\text { juice, Masquerade stick. }\end{array}$ & $\begin{array}{l}\text { Rough-Chaff herb, Mahogany, } \\
\text { Hemorrhage plant, Corpse } \\
\text { Awakener, Bush Candle Tree, } \\
\text { Sand Paper Tree, Starburr, Lemon } \\
\text { juice. }\end{array}$ & $\begin{array}{l}\text { Rough-Chaff herb, Mahogany, } \\
\text { Hemorrhage plant, Corpse } \\
\text { Awakener, Bush Candle Tree, } \\
\text { Sand Paper Tree, Starburr. }\end{array}$ \\
\hline 16 & Typhoid & $\begin{array}{l}\text { Cashew, Pineapple, Dutchman's } \\
\text { pipe, Bitter orange, African } \\
\text { yellow wood, Lecaniodiscus, } \\
\text { Scent Leaf, Lemongrass, Neem } \\
\text { tree, Ginger, Pawpaw, Bitter leaf, } \\
\text { Balloon vine. }\end{array}$ & $\begin{array}{l}\text { Cashew, Pineapple, Dutchman's } \\
\text { pipe, Bitter orange, African } \\
\text { yellow wood, Lecaniodiscus, } \\
\text { Scent Leaf, Lemongrass, Neem } \\
\text { tree, Ginger, Pawpaw, Bitter leaf. }\end{array}$ & $\begin{array}{l}\text { Cashew, Pineapple, Dutchman's } \\
\text { pipe, Bitter orange, African } \\
\text { yellow wood, Lecaniodiscus, } \\
\text { Scent Leaf, Lemongrass, Neem } \\
\text { tree, Ginger, Pawpaw. }\end{array}$ \\
\hline 17 & Ulcer & $\begin{array}{l}\text { Crab's eye, Acalypha, Bhadram, } \\
\text { Goat Weed, Prickly Amaranthus, } \\
\text { Dutchman's pipe, Starburr. }\end{array}$ & $\begin{array}{l}\text { Crab's eye, Acalypha, Bhadram, } \\
\text { Goat Weed, Prickly Amaranthus, } \\
\text { Dutchman's pipe. }\end{array}$ & $\begin{array}{l}\text { Crab's eye, Acalypha, Bhadram, } \\
\text { Goat Weed, Prickly Amaranthus. }\end{array}$ \\
\hline
\end{tabular}

From the results obtained, the Fleiss' kappa agreement analysis recorded a minimum value of 0.26 at D16 (Typhoid) and a maximum value of 0.51 at D14 (Ring Worm) in the first round of the Delphi elicitation technique. In the second round, a minimum value of 0.31 was recorded at D11 (Malaria) and maximum values of 1.00 were recorded at D8 (Eczema) and D14 (Ring Worm). Finally in the third round of the technique, a perfect agreement of 1.00 was recorded for all the ailments. These are shown in Table 5 and Figure 2.

The result of the Fleiss' kappa analysis shows a positive progression towards a perfect agreement of the medicinal plants that are useful in the treatment or management of the various ailments. Most of the ailments recorded a poor agreement at the initial interview which means that some of the medicinal plants obtained at the level might not be useful for the specific ailment it was recorded for or that some medicinal plants that could be useful were left out by some of the experts. This highlights subjectiveness and incompleteness in the elicited knowledge of the experts. However, with the progression of the Delphi technique, these factors were minimized till a perfect agreement was consensus was achieved.

\section{CONCLUSION}

The creation of a consensual knowledge base of medicinal plants and herbs for the treatment and/or management of various diseases in the ATM practice using the Delphi method yielded robust, holistic and non-subjective results. This is because it provided means for the harmonization of the ideas of the various experts recruited for the study. This would have been otherwise impossible if a single interview was conducted for all experts or multiple interviews conducted for a single expert. Achieving non-subjective and complete knowledge of medicinal plants that are useful for the treatment/management of ailments was possible through the elimination of medicinal 
plants and herbs which are not unanimously agreed by the experts as useful in the treatment and/or management of specific ailments. The elicited knowledge was documented as given in Table 4 for the use of both experts and non-experts in the field.

Table 5. Result of the Fleiss' Kappa Agreement Analysis $(k)$

\begin{tabular}{|l|r|r|r|r|r|r|r|r|r|r|r|r|r|r|r|r|r|}
\hline & \multicolumn{1}{|c}{$\mathbf{D}_{\mathbf{1}}$} & $\mathbf{D}_{\mathbf{2}}$ & $\mathbf{D}_{\mathbf{3}}$ & \multicolumn{1}{|c}{$\mathbf{D}_{\mathbf{4}}$} & \multicolumn{1}{c}{$\mathbf{D}_{\mathbf{5}}$} & $\mathbf{D}_{\mathbf{6}}$ & $\mathbf{D}_{\mathbf{7}}$ & $\mathbf{D}_{\mathbf{8}}$ & $\mathbf{D}_{\mathbf{9}}$ & $\mathbf{D}_{\mathbf{1 0}}$ & $\mathbf{D}_{\mathbf{1 1}}$ & $\mathbf{D}_{\mathbf{1 2}}$ & $\mathbf{D}_{\mathbf{1 3}}$ & $\mathbf{D}_{\mathbf{1 4}}$ & $\mathbf{D}_{\mathbf{1 5}}$ & $\mathbf{D}_{\mathbf{1 6}}$ & $\mathbf{D}_{\mathbf{1 7}}$ \\
\hline Rnd 1 & 0.31 & 0.33 & 0.31 & 0.36 & 0.36 & 0.28 & 0.36 & 0.41 & 0.28 & 0.33 & 0.28 & 0.28 & 0.33 & 0.51 & 0.31 & 0.26 & 0.28 \\
\hline Rnd 2 & 0.51 & 0.43 & 0.56 & 0.56 & 0.43 & 0.51 & 0.66 & 1 & 0.65 & 0.48 & 0.31 & 0.38 & 0.48 & 1 & 0.51 & 0.41 & 0.51 \\
\hline Rnd 3 & 1 & 1 & 1 & 1 & 1 & 1 & 1 & 1 & 1 & 1 & 1 & 1 & 1 & 1 & 1 & 1 & 1 \\
\hline
\end{tabular}

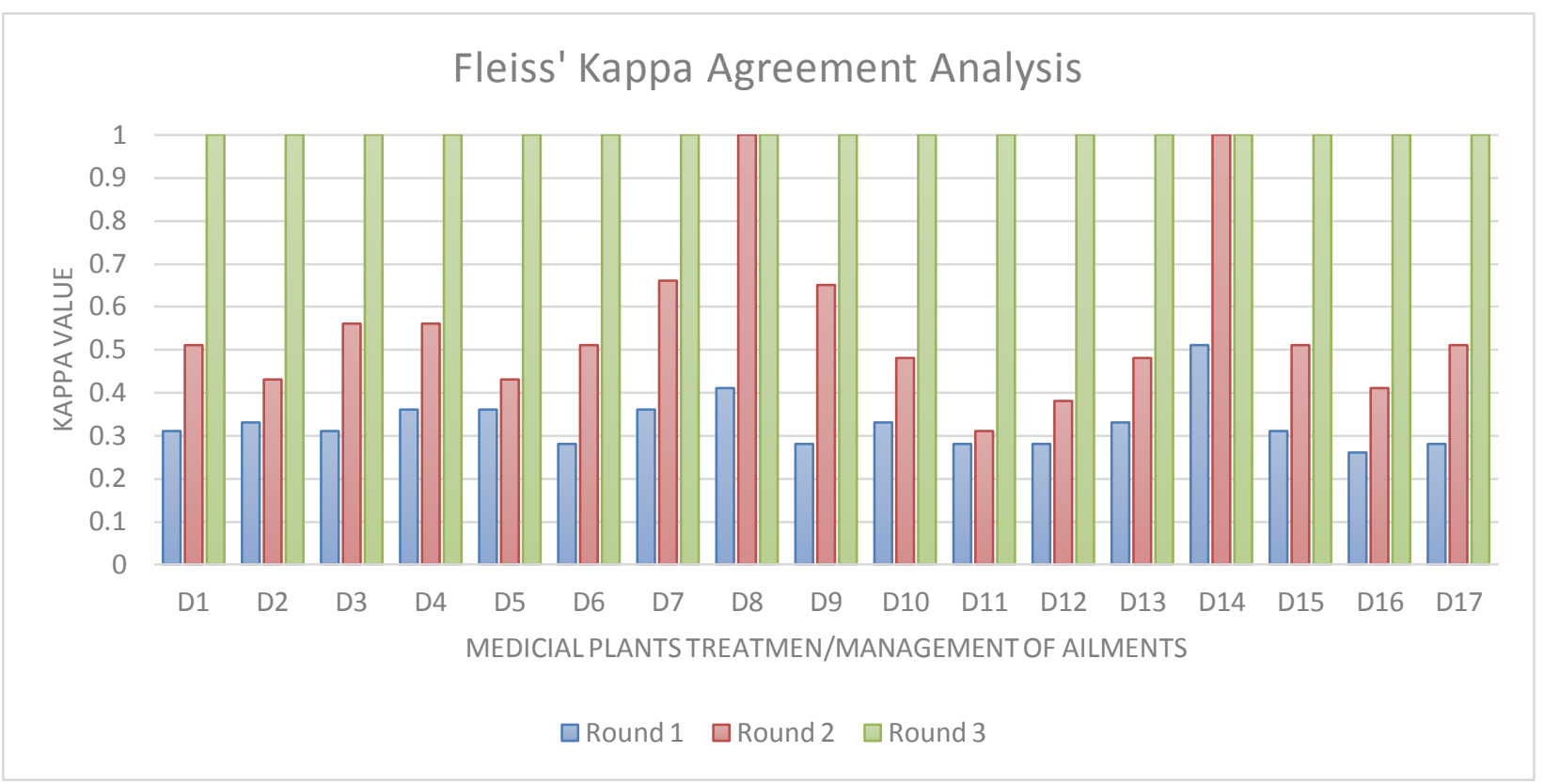

Figure 2. Histogram of the Result of the Fleiss' Kappa Agreement Analysis $(k)$

In conclusion, the application of the Delphi technique in the creation of a knowledge base of medicinal plants and herbs in the ATM practice achieved a consensual, holistic and nonsubjective knowledge base of medicinal plants and herbs. The results obtained from this study aided the development of a knowledge base of medicinal plants of ATM practice which could be used to design ATM information systems and also assist in further researches in the practice.

\section{ACKNOWLEDGMENTS}

Our thanks to the ATM practitioners who shared their knowledge with us and to the contact persons through which we gained access to the practitioners.

\section{REFERENCES}

[1] Beck, H., Dao-Tran, M., and Eiter, T. (2018). LARS: A Logic-based Framework for Analytic Reasoning over Streams. Artificial Intelligence, 261, pp. 16-70.

[2] Sharples, S. Shadbolt, N., and Smart, P. R. (2015) Knowledge Elicitation: Methods, Tools, and Techniques. In, Wilson, John R and Sharples, Sarah (eds.). Evaluation of Human Work. Boca Raton, Florida, USA. CRC Press, pp. 163-200.

[3] Gavrilova, T. and Andreeva, T. (2012). Knowledge Elicitation Techniques in a Knowledge Management Context. Journal of Knowledge Management, 16(4), pp. 523-537, https://doi.org/10.1108/13673271211246112.
[4] Wellsandt, S., Hribernik, K. and Thoben, K. (2014). Qualitative Comparison of Requirements Elicitation Techniques that are used to collect Feedback Information about Product Use. In: Proceedings of 24th CIRP Design Conference, pp. 212-217.

[5] Rusu, O., Halcu, I., Grigoriu, O., Neculoiu, G., Sandulescu, V., Marinescu, M and Marinescu, V. (2013). Converting Unstructured and Semi-Structured Data into Knowledge. Proceedings - RoEduNet IEEE International Conference, pp. 1-4. DOI: 10.1109/RoEduNet.2013.6511736.

[6] Scheurwegs, E., Luyckx, K., Luyten, L., Daelemans, W., and Van den Bulcke, T. (2016). Data Integration of Structured and Unstructured Sources for assigning Clinical Codes to Patient Stays. Journal of the American Medical Informatics Association: JAMIA. 23(1), pp. 1119. DOI:10.1093/jamia/ocv115

[7] Venkatavara P. D., Madhusudanan, S. and Jaganathan, S. (2015). uCLUST-A New algorithm for Clustering Unstructured Data. ARPN Journal of Engineering and Applied Sciences. 10, pp. 2108-2117.

[8] Gharehchopogh, F. S. and Khalifehlou, Z. A. (2011). Analysis and evaluation of unstructured data: Text mining versus natural language processing. 5th International Conference on Application of Information and Communication Technologies 2011, AICT 2011, pp. 1 - 4. DOI: 10.1109/ICAICT.2011.6111017. 
[9] Agbor, A. and Naidoo, S. (2016). A Review of the role of African Traditional Medicine in the Management of Oral Diseases. African Journal of Traditional, Complementary and Alternative Medicines. 13, pp. 133 141. DOI: 10.4314/ajtcam.v13i2.16.

[10] McMillan, S. S., King, M., and Tully, M. P. (2016). How to use the Nominal Group and Delphi Techniques. International Journal of Clinical Pharmacy, 38(3), pp. 655-662. DOI:10.1007/s11096-016-0257-x.

[11] Habibi A., Sarafrazi A., Izadyar S. (2014). Delphi Technique Theoretical Framework in Qualitative Research. Int J Eng Sci. 2014, 3(4), pp. 8-13.

[12] Eddy, Matthew Daniel (2013). The Shape of Knowledge: Children and the Visual Culture of Literacy and Numeracy. Science in Context.26(2), pp. 215245. DOI:10.1017/s0269889713000045.

[13] Audi R. (2010). Epistemology: A Contemporary Introduction to the Theory of Knowledge. $3^{\text {rd }}$ Edition, Routledge, New York. ISBN-13: 978-0415879231.

[14] Girardi D., Kueng J., Holzinger A. (2015). A DomainExpert Centered Process Model for Knowledge Discovery in Medical Research: Putting the Expert-inthe-Loop. In: Guo Y., Friston K., Aldo F., Hill S., Peng H. (eds) Brain Informatics and Health. BIH 2015. Lecture Notes in Computer Science, 9250. Springer, Cham. https://link.springer.com/chapter/10.1007/978-3319-23344-4_38. Assessed on 17th October 2019.

[15] Shadbolt, N. R., and Smart, P. R. (2015). Knowledge Elicitation. In J. R. Wilson \& S. Sharples (Eds.), Evaluation of Human Work (4th ed.). CRC Press, Boca Raton, Florida, USA. http://www.amazon.co.uk/Evaluation-Human-WorkFourthWilson/dp/1466559616/.

[16] O'Hagan, A. (2012). Probabilistic Uncertainty Specification: Overview, Elaboration Techniques and their Application to a Mechanistic Model of Carbon Flux. Environmental Modelling and Software ENVSOFT. 36. DOI:10.1016/j.envsoft.2011.03.003.

[17] Kleiter, G. D. (2018). Imprecise Uncertain Reasoning: A Distributional Approach. Frontiers in Psychology, 9, $2051-2070$.

[18] O'Hagan, A. (2019). Expert Knowledge Elicitation: Subjective but Scientific. The American Statistician, 73(sup1), pp. 69-81, DOI: 10.1080/00031305.2018. 1518265 .

[19] Aniba, M. R., Siguenza, S., Friedrich, A., Plewniak, F., Poch, O., Marchler-Bauer, A., and Thompson, J. D. (2009). Knowledge-Based Expert Systems and a Proofof-Concept Case Study for Multiple Sequence Alignment Construction and Analysis. Briefings in Bioinformatics, 10(1), pp. 11-23. DOI:10.1093/bib/ bbn045.

[20] Papautsky, E. L., Crandall, B., Grome, A., and
Greenberg, J. M. (2015). A Case Study of Source Triangulation: Using Artefacts as Knowledge Elicitation Tools in Healthcare Space Design. Journal of Cognitive Engineering and Decision Making. 9(4), pp. 347-358. DOI: https://doi.org/10.1177/ 1555343415613720.

[21] Raghav, P. R., Kumar, D., and Bhardwaj, P. (2016). Experience of Delphi Technique in the Process of Establishing Consensus on Core Competencies. International Journal of Applied \& Basic Medical Research. 6(3), pp. 191-194. DOI:10.4103/2229516X.186966

[22] Bentley M., Kerr R. and Powell S. (2016). The Use of a Modified Delphi Technique to Inform the Development of Best Practice in Inter-Professional Training for Collaborative Primary Healthcare. Journal of Research in Inter-Professional Practice and Education. Vol. 6. Assessed on $10^{\text {th }}$ September 2018. DOI: http://dx.doi.org/10.22230/jripe.2016 v6n1a 232.

[23] Awoniran, O. M., Soriyan, H. A. and Elujoba, A. A. (2015). A Framework for Knowledge Capture in African Traditional Treatment of Malaria. Nigerian Journal of Natural Products and Medicine. Vol. 19, Pp 126-133. DOI: http://dx.doi.org/10.4314/njnpm .v19i1.15.

[24] Akinyemi, O. V. and Olatokun W. M. (2015). Factors Influencing Indigenous Knowledge Data Elicitation from Herbal Medicinal Practitioners in South-Western Nigeria. African Journal of Sustainable Development. 5(1), pp 97-121. ISSN: 2315-6317.

[25] Elujoba, A. A., Odeleye, O. M. and Ogunyemi C. M. (2005). Traditional Medicine Development for Medical and Dental Primary Health Care Delivery System in Africa. African Journal of Traditional, Complementary and Alternative Medicines, 2(1), pp. 46-61 ISSN: 01896016.

[26] World Health Organization (2000). General Guidelines for Methodologies on Research and Evaluation of Traditional Medicine. WHO/EDM/ TRM/2000.1, pp. 174.

[27] Paulo P. M., Kofi B. and Ossy M. K. (2010). Clinical Practices of African Traditional Medicine. African Health Monitor, Issue 13, World Health Organization Africa.

https://www.aho.afro.who.int/en/ahm/issue/13/reports/cli nical-practices-african-traditional-medicine. Accessed on $10^{\text {th }}$ May 2017.

[28] Gwet, K. L. (2008). Computing Inter-Rater Reliability and its Variance in the Presence of High Agreement. British Journal of Mathematical and Statistical Psychology, 61, pp 29-48.

[29] Marozzi, Marco (2014). Testing for Concordance between Several Criteria. Journal of Statistical Computation and Simulation. 84(9), pp. 1843-1850. DOI:10.1080/00949655.2013.766189. 